\title{
Does the Alberta Tar Sands Industry Pollute? The Scientific Evidence
}

\author{
Kevin P. Timoney ${ }^{*}, 1$ and Peter Lee ${ }^{2}$ \\ ${ }^{I}$ Treeline Ecological Research, 21551 Twp Rd 520, Sherwood Park, Alberta, Canada T8E 1E3; ${ }^{2}$ Global Forest Watch \\ Canada, 10337146 St, Edmonton, Alberta, Canada T5N 3A3, Canada
}

\begin{abstract}
The extent to which pollution from tar sands industrial activities in northeastern Alberta, Canada affects ecosystem and human health is a matter of growing concern that is exacerbated by uncertainty. In this paper we determine whether physical and ecological changes that result from tar sands industrial activities are detectable. We analyze a diverse set of environmental data on water and sediment chemistry, contaminants in wildlife, air emissions, pollution incidents, traditional ecological observations, human health, and landscape changes from the Athabasca Tar Sands region, Canada. Increases in contaminants in water, sediment, and fishes downstream of industrial sources; significant air emissions and major pollution incidents; and the loss of 65,040 ha of boreal ecosystems are documented. Present levels of some contaminants pose an ecosystem or human health risk. The effects of these pollutants on ecosystem and public health deserve immediate and systematic study. Projected tripling of tar sands activities over the next decade may result in unacceptably large and unforeseen impacts to biodiversity, ecosystem function, and public health. The attention of the world's scientific community is urgently needed.
\end{abstract}

\section{INTRODUCTION}

The extent to which pollution from tar sands industrial activities in northeastern Alberta, Canada affects ecosystem and human health is a matter of growing international concern. In spite of that concern, there are to date no comprehensive, peer-reviewed assessments of the cumulative impacts of tar sands development. Issues of tar sands development are dominated by 'grey literature' and most fall into four categories: (1) collections of disciplinespecific reports [1-3]; (2) industrial monitoring reports that present environmental data with a minimum of analyses or context [4]; (3) collections of discipline-specific reports by industrially-controlled consortia [5]; and (4) reports commissioned by non-governmental agencies [6]. Less frequently, graduate theses provide peer-reviewed data on topics such as tailings pond seepage [7] and contaminant effects on nesting birds [8]. Least common are peer-reviewed papers in journals on topics ranging from tailings pond bird landings [9] and sediment contamination [10] to methanogenic bacteria in tailings ponds [11].

The Canadian Environmental Assessment Agency has to date not attempted to assess the environmental effects of Alberta tar sands development. The Canadian Department of Fisheries and Oceans has largely limited its involvement to the issuance of permits and mitigation for the "harmful alteration, disruption or destruction" of fish habitat. The Cumulative Environmental Management Association has similarly been unable to provide a robust synthesis of cumulative impacts. The scientific integrity of reports by the Regional Aquatics Monitoring Program (RAMP) has been questioned [12]. RAMP was found unable to measure and

*Address correspondence to this author at the Treeline Ecological Research, 21551 Twp Rd 520, Sherwood Park, Alberta, T8E 1E3 Canada;

Tel: 780-922-3741; E-mail: ktimoney@interbaun.com assess development-related change locally or in a cumulative way. There were serious problems of scientific leadership and lack of integration and consistency with respect to approach, design, implementation, and analysis.

Concerns about tar sands industrial pollution are exacerbated by uncertainty. Water flow through tar sands geological deposits and peatlands leads to background levels of some contaminants whose concentrations vary both spatially and temporally. This presents challenges to detection of anthropogenic influences. There is, furthermore, a paucity of relevant data available to the public due in large part to a decline in government monitoring in recent decades that has coincided with rapid and major expansion of the tar sands industry. Scientifically-independent data are difficult to obtain because tar sands leases, while public lands, are administered as private property, patrolled by security; public ground access is prohibited. Minimum flight elevation rules hinder meaningful aerial observations.

Pollution from tar sands activities derives from 11 sources: (1) permitted (licensed) discharges to air and land; (2) seepage from tailings ponds; (3) evaporation from tailings ponds; (4) leaks from pipelines; (5) major spills of bitumen, oil, and wastewater; (6) stack emissions; windblown (7) coke dust, (8) dry tailings, and (9) tar sands dust; (10) outgassing from mine faces; and (11) ancillary activities such as transportation, construction of mines, ponds, roads, pipelines, and facilities, and landscape dewatering.

There is an urgent need for information about the impacts of tar sands activities. Much is at stake for the long-term health of humans and ecosystems, the boreal forest, and the world's climate. Here we present analyses of datasets that begin to answer the question: to what degree are tar sands industrial activities detectable? Depending on the nature of the data, the question is addressed in one of four ways. Do present levels of contaminants, regardless of origin, present 
an ecosystem or human health concern? Holding time constant, is there evidence of increased levels of contaminants when sites downstream of industry are compared to sites upstream of industry? Holding sites constant, is there evidence of increased levels of contaminants over time? Are there documented incidents of industrial pollution?

\section{METHODS}

\section{Study Area}

The study area is located in northeastern Alberta's Boreal Forest Natural Region, primarily within its central mixedwood sub-region [13]. The area currently undergoing surface mining straddles the Athabasca River and extends from roughly Ft. McMurray north to the Firebag River (Fig. 1). There the dominant vegetation is a mosaic of white spruce (Picea glauca) and aspen (Populus tremuloides) forests on fine-textured Gray Luvisolic upland soils; jack pine (Pinus banksiana) forests on sandy Brunisolic uplands; riparian balsam poplar (Populus balsamifera) forests and willow (Salix spp.) carrs on silty alluvial Regosols; and open, shrub willow, and treed (Picea glauca, P. mariana, and Larix laricina) fens and bogs on poorly-drained Organic Mesisols and Fibrisols. The Athabasca River, incised to a depth of about $60-70 \mathrm{~m}$ below the plain, is the dominant landscape feature of the area. Recent average discharge of the Athabasca River below Ft. McMurray is $503 \mathrm{~m}^{3} / \mathrm{sec}$ (2000-2007, Water Survey of Canada data). Ft. McMurray mean annual temperature is $0.1 \mathrm{C}$; annual precipitation is $444 \mathrm{~mm}$ (Environment Canada data, Ft. McMurray airport, n $=60$ and 59 years).

To date, most development has focussed on extracting bitumen through surface mining of Cretaceous McMurray Formation deposits. Bitumen is a viscous mixture of hydrocarbons that contains about $83 \%$ carbon, $10 \%$ hydrogen, $5 \%$ sulphur, $1 \%$ oxygen, $0.4 \%$ nitrogen, and trace quantities of methane, hydrogen sulphide, and metals. The deposits are referred to as "tar sands" or "oil sands", although the technically correct term is bitumen sands. By area, about $20 \%$ of the Athabasca deposits can be surface

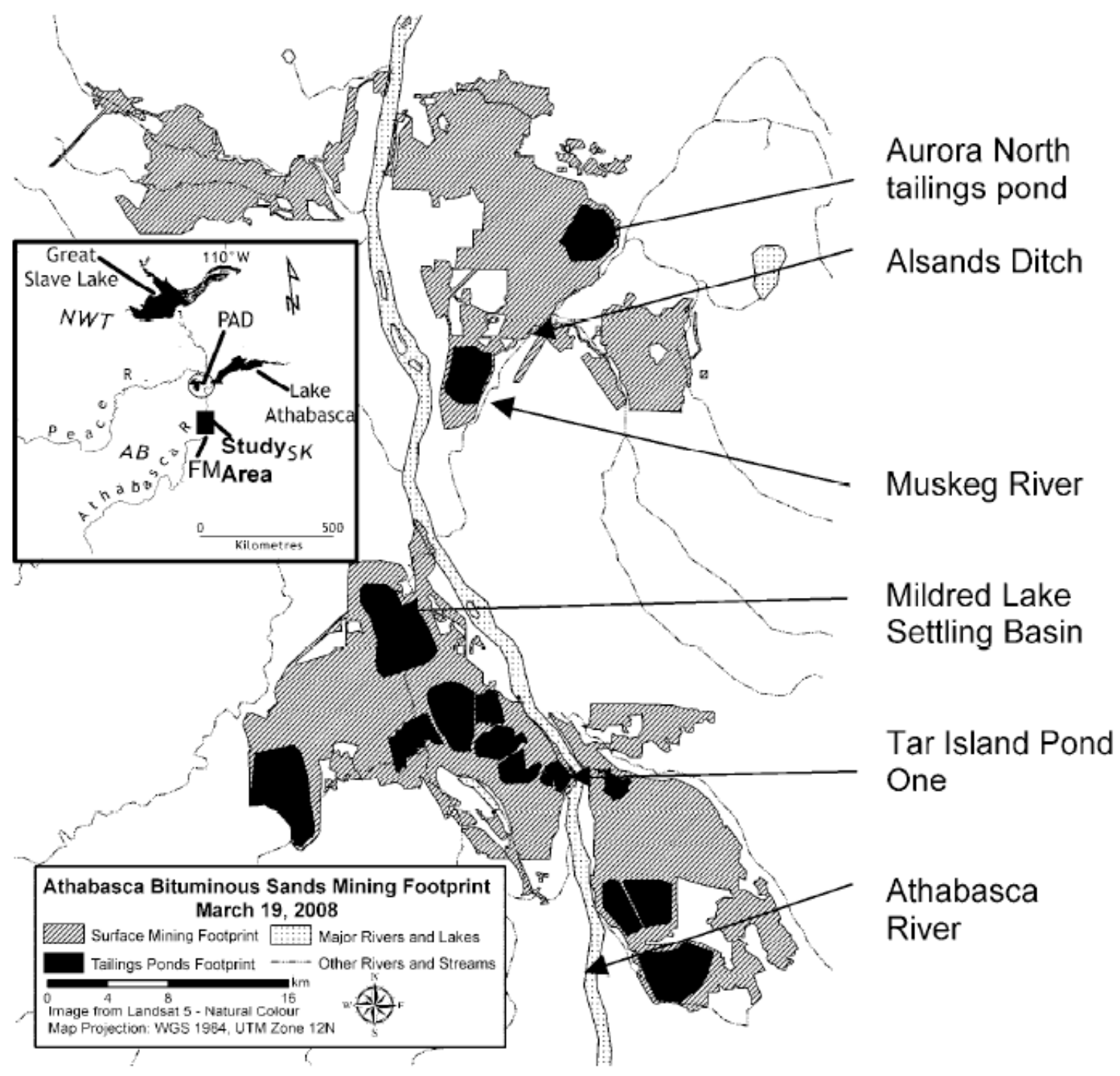

Fig. (1). Athabasca tar sands industrial footprint (hachured) as of March 2008. Inset shows the study area within the regional context; abbreviations: $\mathrm{AB}=$ Alberta, FM = Fort McMurray, NWT = Northwest Territories, PAD = Peace-Athabasca Delta and Fort Chipewyan, SK $=$ Saskatchewan. 
mined. The remainder requires in situ well-based methods such as steam-assisted gravity drainage to recover bitumen in deposits lying too deep to surface mine.

The Muskeg River [14] is a brown-water stream; calcium and bicarbonate are its major ions. Peatlands cover $50-90 \%$ of the area of some sub-basins and are the main source of the river's high levels of dissolved organic carbon. The river is somewhat alkaline and well-buffered; suspended solids and turbidity are low; dissolved oxygen is low during the period of ice cover. The majority of the river's discharge appears to derive from shallow groundwater, much of which may flow through shallow organic soils at the peat/mineral interface. Discharges to the Muskeg River from tar sands activities in 2006 were estimated at 2.53 billion L [5]. The proportion of this volume represented by tailings was not specified, but such a discharge represented about $3.6 \%$ of total flow of the Muskeg River in 2006.

Suncor's Tar Island Pond One (tailings pond) and the Tar Island Dyke (TID) separating it from the Athabasca River were the first such built in the industry. A tar sand tailings pond contains the residue or tails left after bitumen is extracted from the sand, which consists of process water, sand, fines (silts and clays), residual bitumen (1-5\%), and associated chemicals. TID was constructed over the period 1965 to 1980 to a height of $\sim 91 \mathrm{~m}$ and a length of $3.5 \mathrm{~km}$ perched above the Athabasca River (Fig. 1). Sand tailings were placed hydraulically to build the dyke while fine tailings and process-affected water were discharged into the pond [7]. A shallow layer of process water covers the pond which overlies fine tailings that become more consolidated with depth. Tailings process water, thin layers of consolidated fine tailings, and residual bitumen are found within the dyke [7]. The dyke is constructed on a weak foundation of alluvial clay and, in response to high thrust, has undergone a history of lateral creep [15]. The tailings pond covers $\sim 145$ ha, $1.2 \%$ of the total area of tailings ponds as of spring 2008.

\section{Analyses and Data Sources}

A Muskeg River polycyclic aromatic hydrocarbon (PAH) dataset was analyzed [raw data from 5]. Semipermeable membrane devices (SPMDs) were deployed at two sites in the Muskeg River during summer 2006 from 25 July to 27 August. Site MUR-6 was located upstream of development; Site MUR-5 was located downstream of tar sands industrial development. Data were edited to avoid double-counting of some PAHs. Corrected PAH concentrations were the observed values minus the corresponding trip blanks. For analytes in which the trip blank was greater than either of the observed values, corrected values were not calculated. Analytes that failed to meet quantification criteria were deleted. Day 0 and trip blanks were the mean of two values standardized to 4 SPMDs per sample. For sites MUR-5 and MUR-6, values are the mean of four SPMDs. The effect of upstream vs. downstream position was quantified in two ways: by the ratio of downstream (MUR-5) concentration to upstream (MUR-6) concentration, and by the difference between downstream and upstream concentration.

A spreadsheet of RAMP sediment PAH concentrations from sites in the Athabasca River Delta was obtained courtesy of the Mikisew Cree First Nation. Values were calculated by summing the concentration of the individual alkylated PAH species. Concentrations of mercury in Lower Athabasca River walleye tissue were obtained in tabular form from the literature. For both PAHs and mercury, statistics were calculated from the raw data.

Data on the concentrations of 24 dissolved analytes from porewater in the sediment of the Athabasca River upstream and downstream of Tar Island Pond One provided a test of whether tailings pond seepage effects could be detected in Athabasca River sediments. For Tar Island Pond One, Sites 1 and 6 [raw data from 16] were used to test for an influence of the pond on the porewater chemistry of the Athabasca River. Site 1 was upstream of the pond; Site 6 was downstream of the pond and upstream of the Suncor wastewater pond outfall. Porewater data were gathered from a depth of $0.3 \mathrm{~m}$ beneath the sediment near the west bank of the Athabasca River.

The areal extent of habitat loss was determined for the study area through overlay of the tar sands mining footprint (March 2008) onto pre-disturbance land cover polygons from three datasets: (1) the Alberta Peatlands Inventory [17]. Wetlands were mapped and digitized from the most recent available 1:40,000 black and white airphotos. Fens and bogs dominated the wetland types in the peatland inventory; marshes and swamps were too limited in extent to be mapped as individual polygons. (2) For lands disturbed after 2000, Earth Observation for the Sustainable Development of Forests (EOSD, Canadian Forest Service, vintage circa 2000; scenes 07D_1c_1, 07E_lc_1). Shrublands and undifferentiated wetlands classified in the EOSD data that did not correspond to a wetland polygon in the Alberta peatland inventory data were retained as a separate category. (3) For non-wetlands disturbed prior to 2000, Global Forest Watch Canada digitized EOSD land cover type polygons onto six black and white vertical airphotos, scale 1:63,360, vintage 1949-1951, Alberta Dept. of Lands and Forests images 74E03, 04, 05, 06, 74D13, 14). The surface mining footprint includes only mines, tailings ponds, facilities, and infrastructure local to those. It excludes wells, pipelines, and most roads as those disturbances extend beyond the single Landsat scene analyzed at multiple dates. As such, the estimate is conservative. Nomenclature for plants follows Moss [18]; that for birds follows AOU [19]; and that for fishes follows Scott and Crossman [20].

\section{RESULTS}

\section{Tar Sands Development and the Concentration of PAHs in the Muskeg River}

Of the 28 species of PAHs for which differences in upstream and downstream concentrations could be calculated, 26 increased in concentration downstream (Table 1, Fig. 2). Low molecular weight PAH species $(n=17)$ increased downstream of development by factors of 6.1 (mean) and 4.7 (median). The largest increases in concentration ratios were observed for $\mathrm{C} 2$ and $\mathrm{C} 3$ dibenzothiophenes, C2 and C3 fluorenes, and C2 phenanthrenes/ anthracenes, in which downstream concentrations were 9-15 times higher than upstream concentrations. Typical increases in concentrations of individual PAHs downstream of development were $348 \mathrm{ng} / \mathrm{sample}$ (mean) and $171 \mathrm{ng} / \mathrm{sample}$ 
Table 1. Concentrations of PAHs in Water Upstream (u/s) and Downstream (d/s) of Development in the Muskeg River, Summer 2006 $^{\wedge} * *$

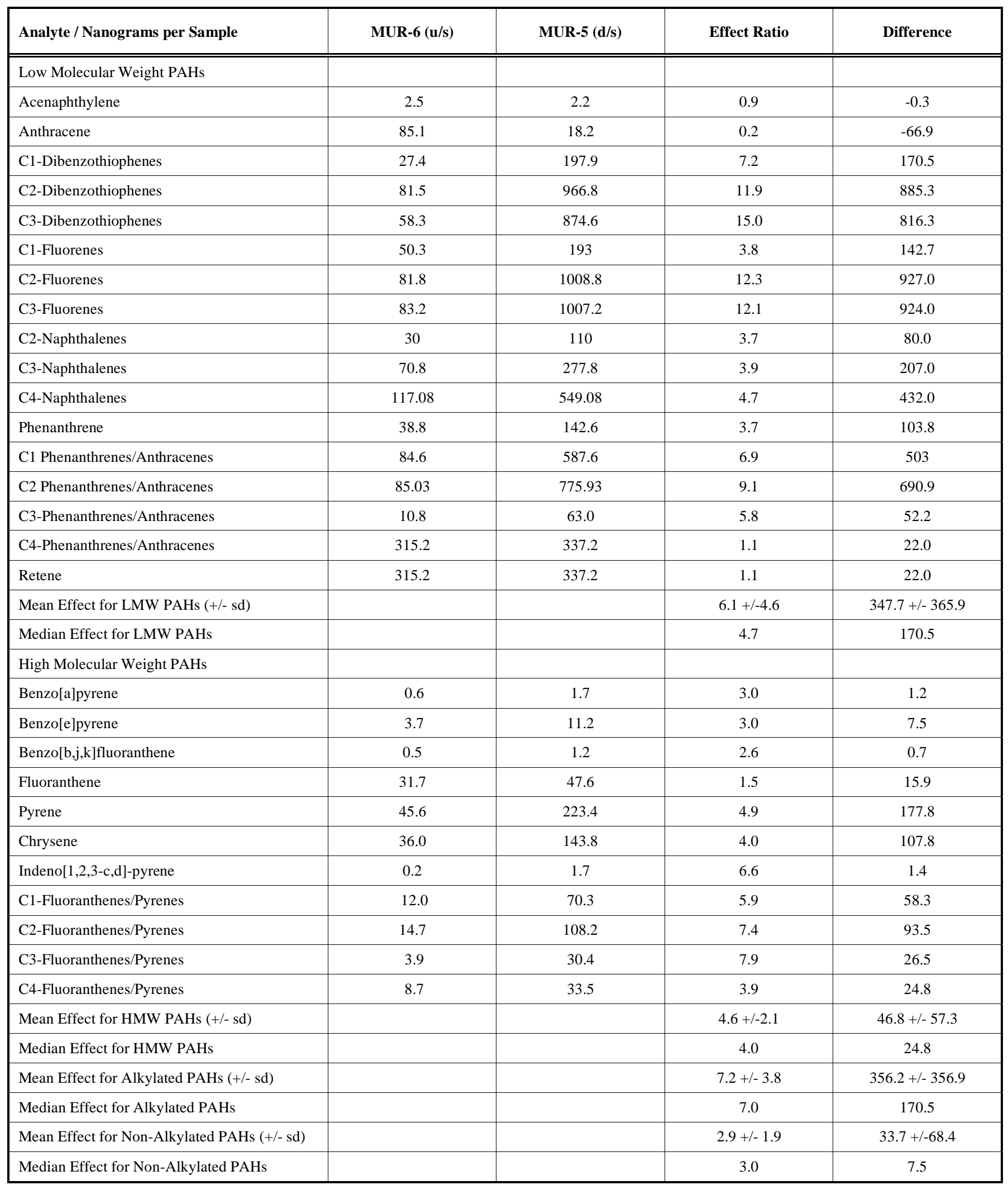

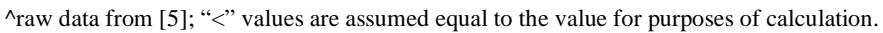

*Effect Ratio is the ratio of downstream/upstream PAH concentrations; if $>1$, concentration increases downstream by that factor; Difference is the change in concentration from the

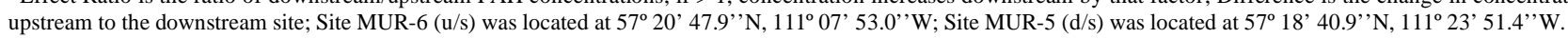




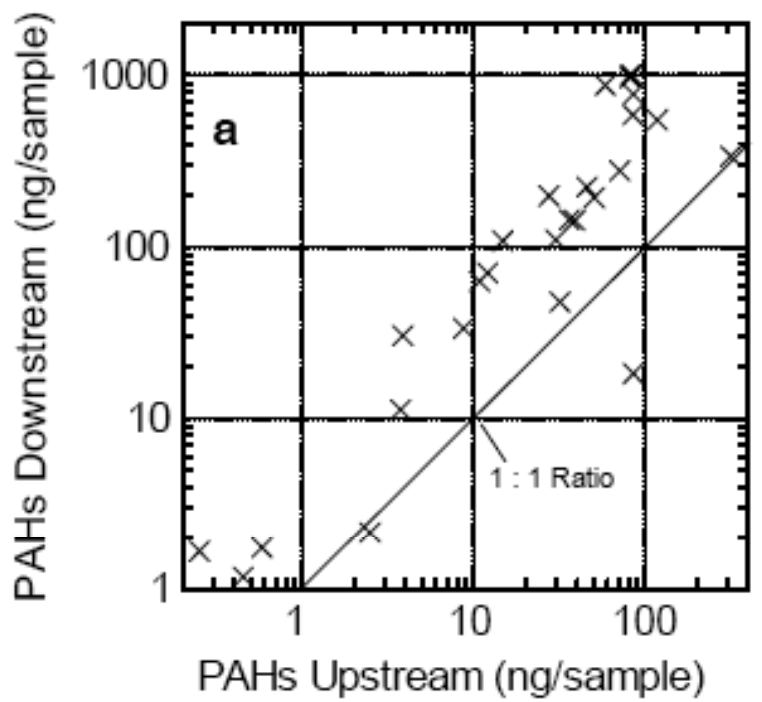

b

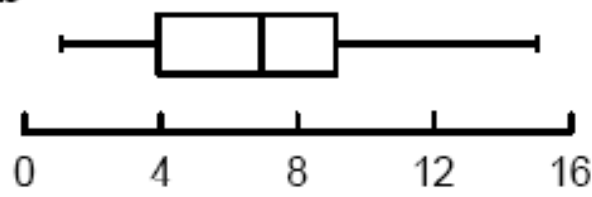

Effect Factor (Downstream : Upstream)

C
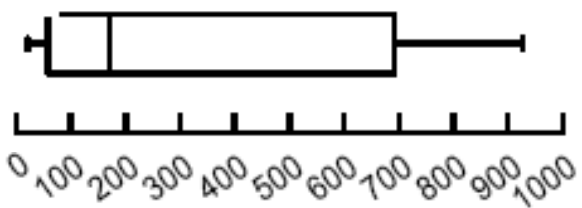

Difference in Concentration ( $\mathrm{ng} / \mathrm{sample}$ )

Fig. (2). (a) Relationship between concentrations of 28 PAHs in the Muskeg River upstream and downstream of industrial oil sands development (raw data from [21]). Some points overlap; axes are $\log 10$ transformed. (b) Ratio of downstream : upstream alkylated PAH concentrations. (c) Difference in concentration for alkylated PAHs between downstream and upstream sites $(\mathrm{n}=17)$.

(median) for low molecular weight PAHs. The largest increases in concentration (432-885 ng/sample) were observed for $\mathrm{C} 2$ and $\mathrm{C} 3$ dibenzothiophenes, C4 naphthalenes, and C2 phenanthrenes/anthracenes. For alkylated species $(n=17)$, PAH concentrations increased downstream of development by factors of 7.2 (mean) and 7.0 (median); increases in concentrations downstream of development were $356 \mathrm{ng} / \mathrm{sample}$ (mean) and $171 \mathrm{ng} / \mathrm{sample}$ (median) (Fig. 2). Increases in concentrations downstream of development were statistically significant for all PAHs as a group (Mann-Whitney test, $\mathrm{U}=565, \mathrm{p}=0.005, \mathrm{n}=28$ ). A strong relationship existed between low molecular weight PAH concentrations and tar sands development $(U=236, p$ $=0.002, \mathrm{n}=17)$. The strongest relationship existed between alkylated PAH concentrations and tar sands development (U $=246, \mathrm{p}=0.0005, \mathrm{n}=17$ ); the relationship for non-alkylated PAHs was not significant $(\mathrm{U}=72, \mathrm{p}=0.450, \mathrm{n}=11)$.

\section{Lower Athabasca River PAHs and Mercury}

Over the period 1999-2007, concentrations of alkylated PAHs increased in Athabasca River Delta sediment (Fig. 3). Alkylated PAH concentrations were correlated significantly with both year and Athabasca River annual discharge (Pearson $r=0.38,0.52, p=0.03,0.005$ ), indicating that both a temporal trend and a hydrologic relationship may be in effect. Reconstruction of PAH concentrations through analysis of dated sediment cores is needed to elucidate trends in lower Athabasca River sediment PAHs.

Mean mercury concentrations in lower Athabasca River walleye increased over the period 1976 to 2005 (Fig. 4). Lower Athabasca River walleye (Stizostedion vitreum) and lake whitefish (Coregonus clupeaformis) sampled in September 2005 posed a human health risk (Table 2). Virtually all walleye longer than $40 \mathrm{~cm}$ or weighing more than $500 \mathrm{~g}$ contained more than $0.20 \mathrm{mg} / \mathrm{kg}$ of mercury, the Health Canada subsistence fisher guideline. Under US EPA standards, all walleye, all female whitefish and $\sim 90 \%$ of male whitefish exceeded subsistence fisher consumption guidelines.

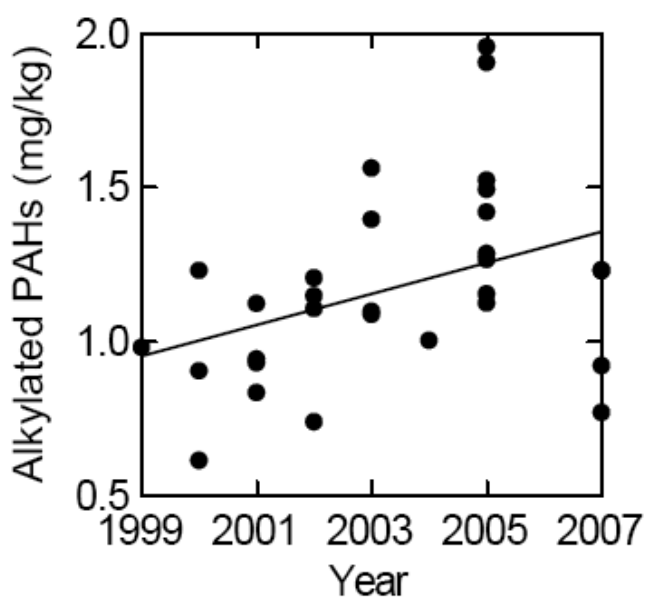

Fig. (3). Trends in alkylated PAH concentrations from Athabasca River Delta sediment. Raw data from RAMP. Some data points overlap; line is a least-squares linear regression.

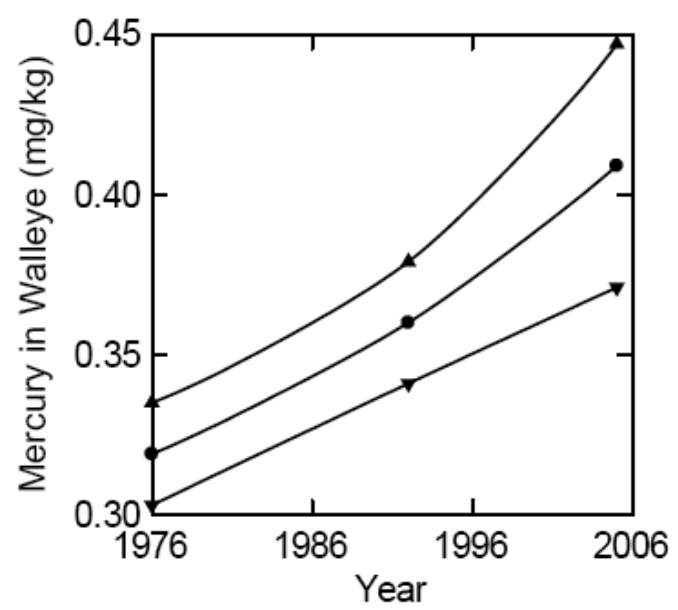

Fig. (4). Trend in mean mercury concentration (+/-1 SE) in muscle of mature walleye of the lower Athabasca River. Raw data: 1976, $n$ $=59$, from [94]; 1992, $\mathrm{n}=12$, from [95]; 2005, $\mathrm{n}=25$, from [21]. 
Table 2. Concentration of Mercury $(\mathrm{mg} / \mathrm{kg}$, Wet Weight) in Muscle of Mature Lake Whitefish and Walleye from the Lower Athabasca River, September 2005^

\begin{tabular}{|c|c|c|c|c|}
\hline & \multicolumn{2}{|c|}{ Whitefish (Hg mg/kg) } & \multicolumn{2}{|c|}{ Walleye (Hg mg/kg) } \\
\hline Mean & 0.081 & 0.106 & 0.352 & 0.510 \\
\hline Median & 0.073 & 0.105 & 0.259 & 0.464 \\
\hline Maximum & 0.170 & 0.160 & 0.765 & 0.694 \\
\hline $95 \%$ CI, upper & 0.101 & 0.133 & 0.478 & 0.595 \\
\hline $95 \%$ CI, lower & 0.061 & 0.079 & 0.225 & 0.425 \\
\hline Normality $(\mathrm{p})^{*}$ & 0.445 & 0.850 & 0.246 & 0.709 \\
\hline $\mathrm{N}$ & 15 & 11 & 16 & 9 \\
\hline
\end{tabular}

$\wedge$ Raw data from [21].

*Kolmogorov-Smirnov one-sample normality test, two-tailed $\mathrm{p}$.

Table 3. Porewater Dissolved Analyte Concentrations at Depth of $0.3 \mathrm{~m}$ in the Sediment of the Athabasca River at Site 1 (Upstream) and Site 6 (Downstream) of Tar Island Pond One ${ }^{\circledR}$

\begin{tabular}{|c|c|c|c|c|c|}
\hline Ammonia as $\mathrm{N}$ & 2.16 & 7.8 & 5.64 & 3.6 & 1.37 at $\mathrm{pH} 8,10 \mathrm{C} \#$ \\
\hline Antimony & 0.0006 & 0.004 & 0.0034 & 6.7 & \\
\hline Arsenic & 0.0029 & 0.0147 & 0.0118 & 5.1 & 0.005 \\
\hline Bismuth & $<0.00005$ & 0.00005 & 0.000025 & 2.0 & \\
\hline Boron & 0.034 & 0.028 & -0.006 & 0.8 & \\
\hline Chromium & 0.0006 & 0.0014 & 0.0008 & 2.3 & $\begin{array}{c}0.0089 \text { trivalent, } 0.001 \\
\text { hexavalent }\end{array}$ \\
\hline Cobalt & 0.011 & 0.006 & -0.005 & 0.5 & \\
\hline Lead & $<0.0001$ & 0.0014 & 0.00135 & 28.0 & $0.002-0.004^{\wedge}$ \\
\hline Lithium & 0.0117 & 0.0195 & 0.0078 & 1.7 & \\
\hline Manganese & 7.28 & 7.54 & 0.26 & 1.0 & \\
\hline Molybdenum & 0.0054 & 0.0043 & -0.0011 & 0.8 & 0.073 \\
\hline Nickel & 0.0102 & 0.0048 & -0.0054 & 0.5 & $0.065-0.110^{\wedge}$ \\
\hline Selenium & $<0.0004$ & 0.0006 & 0.0004 & 3.0 & 0.001 \\
\hline Silver & $<0.0002$ & 0.0002 & 0.0001 & 2.0 & 0.0001 \\
\hline Strontium & 0.449 & 1.69 & 1.241 & 3.8 & \\
\hline Titanium & 0.0045 & 0.0129 & 0.0084 & 2.9 & \\
\hline
\end{tabular}

${ }^{@}$ Site 1 at $56^{\circ} 55^{\prime} 56.1^{\prime \prime} \mathrm{N}, 111^{\circ} 26^{\prime} 44.3^{\prime \prime} \mathrm{W}$ (sampled 9 Oct 2004); Site 6 at 56 59' $58.3^{\prime \prime} \mathrm{N}, 111^{\circ} 27^{\prime} 29.0^{\prime \prime} \mathrm{W}$ (sampled 13 Oct 2004). Raw data from [16].

*CCME freshwater aquatic life protection guideline [22]; --- indicates no CCME guideline; ${ }^{*}$ data from [23]; ^depends on hardness (= 77-160 mg/L for Athabasca R. near Donald Cr.) 


\section{Influence of Tar Island Pond One on Athabasca River Porewater Dissolved Analytes}

Of 24 analytes, the concentration of 19 analytes increased downstream of the pond while that of five decreased (Table 3). Overall, median and mean increases in concentration downstream of the pond were 2-fold and 4-fold, respectively. In terms of water quality guidelines, analytes of primary concern were ammonia, arsenic, iron, and zinc. Nine analytes increased three- or more-fold downstream of the pond; none decreased three- or more-fold. Analytes that increased at least three-fold were ammonia, aluminum, antimony, arsenic, copper, lead, strontium, uranium, and zinc.

\section{Landscape, Habitat, and Wildlife Losses}

The Athabasca tar sands industrial footprint as of spring 2008 was 65,040 ha, composed of 12,058 ha of tailings ponds and 52,982 ha of pits, facilities, and infrastructure (Fig. 1, Table 4). Boreal coniferous and deciduous upland and riparian forests, water bodies, exposed/disturbed soils, and a diverse array of bog and fen wetlands and shrublands have been lost. Within the industrial footprint, most of the native biota, composed of thousands of species and millions of individuals, have been extirpated. By proportion of the footprint, the largest losses have been to coniferous forest $(36.0 \%)$ and deciduous forest $(24.6 \%)$. Between 1992 and 2008 , the extent of tailings ponds grew by $422 \%$ while the extent of mine pits, facilities, and infrastructure grew by $383 \%$ (Table 5).

Based on typical Canadian western boreal bird densities by habitat $[24,25]$, the observed loss of deciduous forest translates to a permanent loss in the range of 24,918 to 83,060 birds, a coniferous forest loss of 24,832 to 146,178 birds, and a fen, bog, and shrubland/undifferentiated wetland loss of 8,301 to 173,102 birds, for a total 58 to 402 thousand birds lost from the regional population. These losses are in addition to the annual bird mortalities due to tailings pond exposure (see Impacts Upon Birds).

\section{DISCUSSION}

\section{Muskeg River PAHs}

Tar sands development increases the concentrations of PAHs in the Muskeg River, particularly of the alkylated forms characteristic of petrogenic sources. Withdrawal of Muskeg River water by tar sands operations between sites MUR-6 and MUR-5 was considered as a possible explanation for increased PAH concentrations. During 2006, discharge at the downstream site was about three times greater than discharge at the upstream site. Withdrawal of water is not a factor in the higher PAH levels observed at MUR-5.

Tar sands mining is the most parsimonious explanation for elevated PAH levels between sites MUR-6 and MUR-5. MUR-5 lies near the Syncrude Aurora North Mine and tailings pond and downstream of Stanley Creek, a tributary disturbed by active tar sands mining. Stanley Creek receives drainage from, and flows through, a portion of the open pit mine; it then flows along the north and east sides of the Aurora North tailings pond before joining with the Muskeg River upstream of MUR-5. When observed from a helicopter by Timoney during August 2006, Stanley Creek was undergoing diversion. Sediments collected from Stanley

Table 4. Areal Extent (ha, \% of total) of Habitat Loss Due to Tar Sand Industrial Activities in the Athabasca Tar Sands Region as of 19 March 2008

\begin{tabular}{|l|c|l|}
\hline \multicolumn{1}{|c|}{ Pre-Mining Cover Type } & Extent (ha, \%) & \multicolumn{1}{c|}{ Comments } \\
\hline \hline Water & $490,0.75$ & rivers, ponds, lakes \\
\hline Exposed & $735,1.13$ & sparsely vegetated mudflats, sandbars, recent cutblocks and burns \\
\hline Coniferous Forest & $23,426,36.02$ & \\
\hline Deciduous Forest & $15,973,24.56$ & \\
\hline Fens & $10,556,16.23$ & \\
\hline Bogs & $449,0.69$ & \\
\hline Shrublands, Undifferentiated Wetlands & $13,411,20.62$ & $\begin{array}{l}10,719 \text { ha shrublands and 2,692 undifferentiated wetlands; total wetland loss (fens, bogs, } \\
\text { shrublands, undifferentiated wetlands) }=24,416 \text { ha, 37.54\% }\end{array}$ \\
\hline
\end{tabular}

Table 5. Athabasca Tar Sands Industrial Footprint by Year*

\begin{tabular}{|c|c|c|c|}
\hline Year & Tailings Ponds (ha) & Pits, Facilities, Infrastructure (ha) & Total Footprint (ha) \\
\hline \hline 1974 & 230 & 3,726 & 3,956 \\
\hline 1992 & 2,855 & 13,849 & 16,704 \\
\hline 2002 & 10,329 & 23,194 & 33,523 \\
\hline 2008 & 12,058 & 52,982 & 65,040 \\
\hline
\end{tabular}

*Scenes: 1974, Multi-spectral scanner, p046r20_1m19740820, 20 August 1974 1992, Landsat thematic mapper, P042R20_5T920611, 11 June 1992 2002, Landsat enhanced thematic mapper, p042r020_7t20020514, 14 May 2002 2008, Landsat thematic mapper, 4220_080319, 19 March 2008. 
Creek in 2003 were high in total hydrocarbons, organic carbon, retene, and many alkylated PAHs [26]. The tailings pond "Muskeg River Sump" is located about $250 \mathrm{~m}$ northwest of the MUR-5 site [4].

The most abundant PAHs in the Aurora North tailings pond [4, in fine tails $21 \mathrm{~m}$ zone] correspond closely with the Muskeg River PAHs whose concentration increased the most downstream of the pond. C2 phenanthrene/anthracene was the most abundant PAH in the Aurora North tailings pond, C3 dibenzothiophene was the second, C2 dibenzothiophene was the fourth, and C2 fluorene was the sixth most abundant $\mathrm{PAH}$ in the tailings pond (no data were presented by Syncrude [4] for C3 fluorene).

\section{Lower Athabasca River PAHs and Mercury}

PAH concentrations in sediment cores from Richardson Lake and Lake Athabasca were determined by Evans et al. [27] for 1950 and 1998. Total PAH levels increased with time in Richardson Lake and decreased with time in Lake Athabasca. Unfortunately, those data are now a decade old and much development has taken place since 1998. Sediments from the lower Athabasca River and its delta have been found toxic to several species of invertebrates [28] and contain high levels of PAHs and metals [21]. There are presently no Canadian guidelines for total PAHs in sediment. A study conducted for the US National Oceanic and Atmospheric Administration [29] recommended a threshold of $1 \mathrm{mg} / \mathrm{kg}$ dry weight of total PAHs in marine sediment for protection of estuarine fish populations. Above $1 \mathrm{mg} / \mathrm{kg}$ total PAHs, there was a substantial increase in the risk of liver disease, reproductive impairment, and potential effects on growth. The PAH signature in ARD sediments is consistent with that of tar sands bitumen. Levels of PAHs in sediment of the Athabasca River are about twice that observed to induce liver cancers in fishes [30].

The cumulative landscape disturbance resulting from clearcutting, burning, excavation and stockpiling of peat, and wetland dewatering associated with the expanding tar sands operations may account for the increasing methylmercury levels observed in lower Athabasca River walleye. Disturbed wetlands and soils are recognized as important sources of methylmercury, and fish mercury concentrations in boreal lakes have been correlated with areal extent of watershed disturbance $[31,32]$. Recent determinations of tissue mercury in other fish species are also cause for concern. Fillets of lake whitefish, sucker (Catostomus), and goldeye (Hiodon alosoides) contained $0.18-5.9 \mathrm{mg} / \mathrm{kg}$ of mercury $(\mathrm{n}=28)$ while fillets of northern pike (Esox lucius), walleye, burbot (Lota lota), and lake trout (Salvelinus namaycush) contained $0.1-3.4 \mathrm{mg} / \mathrm{kg}$ of mercury $(\mathrm{n}=45)$ [33]. Under US EPA subsistence fisher guidelines, all of these fishes would be considered unsafe to eat.

\section{Tailings Pond Seepage}

Tar Island Pond One seepage affects the concentrations of a host of dissolved analytes in the sediment porewater of the Athabasca River by a factor of 2-4-fold. Eight analytes bound to sediments at Site 6 exceed maximum ambient concentrations: C2 naphthalene, barium, beryllium, boron, strontium, thallium, titanium, and uranium. At an Athabasca River surface water site adjacent to Site 6 (PD1-93-13-SW), six dissolved analytes have been found to exceed either water quality guidelines or maximum ambient concentrations (beryllium, chromium, manganese, strontium, vanadium, and naphthenic acids; [16]).

Seepage of tailings water from the Tar Island Pond One into groundwater hydraulically connected to the Athabasca River has been quantified at 5.5-5.7 million L/day [7, 34]. Leakage rates would be higher were it not for a low permeability silt and clay layer underlying the pond. Total flow through the sand aquifer to the river is estimated at $4,250 \mathrm{~L} / \mathrm{sec}$ [7]. Leakage from the pond appears to be primarily "process affected water" that was introduced into the dyke during its construction. As part of an assessment of the ecological risk posed by Tar Island Pond One, Komex [16] identified chemicals of potential ecological concern as arsenic, ammonia, barium, chromium, bismuth, iron, lithium, manganese, naphthenic acids, selenium, strontium, tin, vanadium, zinc, methylnaphthalene and $\mathrm{C} 2$ naphthalene.

Alberta government technical staff [35] acknowledged escape of tailings from the Aurora North tailings pond when it advised Syncrude that it hoped construction of a soilbentonite wall would reduce or eliminate further seepage of process water. The seepage occurs adjacent to Stanley Creek, a tributary of the Muskeg River. On the Suncor lease, the pond known as "Natural Wetland" contains elevated levels of hydrocarbons, naphthenic acids, and salinity due to seepage of tailings water through the adjacent containment dyke [36].

Seepage from the Syncrude Mildred Lake site is implied in the high concentration of naphthenic acids found in Beaver Creek [37] and in high and increasing levels of naphthenic acids downstream of the "lower seepage dam" [38]. Government correspondence with Syncrude shows that the government suspects seepage off the Syncrude site [39]. Excerpts: "Explain the increasing chloride concentration (76 $\mathrm{mg} / \mathrm{L}$ ) at sample location BRC in 2007... Wells ... continue to clearly show increasing chloride concentrations not reflective of background chemistry... This is all indicative of an advancing plume... Wells with elevated chloride ... indicate increasing chloride concentrations... Explain the increasing naphthenic acid concentration $(60 \mathrm{mg} / \mathrm{L})$ in monitor well OW98-09..."

The total seepage rate for all tailings ponds has recently been estimated under five scenarios that differed in assumptions of how seepage rates change over time. The 'report' scenario released to the public estimated a current escaped seepage rate of 11 million $\mathrm{L} /$ day and a projected peak seepage rate of 26 million L /day in the year 2012 [40]. The other four scenarios estimated current escaped seepage rates of from 7 to 36 million L / day [41]. Current production of tailings from all facilities is 1.8 billion L/day [6]. Leakage of toxins from tailings ponds may be a concern for decades if not for centuries.

\section{Wildlife, Landscape, and Habitat Losses}

The effect that such habitat conversion has had on wildlife populations has not been assessed. In 2005, 51 black bears (Ursus americanus) were destroyed at tar sands facilities and their work camps, 14 of which were destroyed at the Petro-Canada Mackay River project [42]. Ancillary wildlife losses may be significant, but as with bird 
mortalities, the lack of systematic monitoring raises more questions than answers. Mammal mortality data gathered through industrial self-monitoring were released to Timoney (23 February 2009) under a government freedom of information request. During 22 combined years of operation (at Suncor, Syncrude, and Shell Albian Sands), the companies reported a total of 162 dead individuals, including one marten (Martes americana), one southern red-backed vole (Clethrionomys gapperi), and one "weasel" (Mustela sp.). Clearly such ad hoc observations present a gross underestimate of actual mortality.

Wildlife impacts independent of habitat conversion can result from landscape fragmentation, increased access, and industrial noise. Areas near noiseless energy facilities in Alberta can have a total passerine bird density 1.5 times higher than that in areas near noise-producing energy sites [25]; the abundance of one-third of the species was reduced by noise. The impacts of wholesale landscape transformation on regional populations, diversity, and provision of ecosystem goods and services remain uninvestigated.

The proportion of landscape converted to tar sands mining varies by watershed from $<1 \%$ to $5-10 \%$ (e.g., Muskeg River) to $>10 \%$ (e.g., Beaver, McLean, and Tar watersheds) [5]. Major reaches of streams have been diverted (e.g., Beaver River, McLean Creek). Entire reaches of the Beaver, Tar, and Calumet Rivers and Poplar and McLean Creeks have been obliterated. The harmful alteration, destruction or disruption ("HADD") of 1.28 million $\mathrm{m}^{2}$ of fish habitat within the Muskeg River and its tributaries by Imperial Oil has been approved by the federal Dept. of Fisheries and Oceans (HADD permit ED-03-2806).

\section{Other Evidence of Environmental Impacts and Pollution in the Lower Athabasca River Region}

\section{Impacts Upon Birds}

Spring migration in northeastern Alberta poses a serious threat to birds. The area is located along a convergence zone of migratory bird flyways en route to the Peace-Athabasca Delta, the most important waterfowl staging area in Canada [43]. As of spring 2008, the areal extent of tailing ponds within the study area exceeded the extent of natural water bodies by $42 \%$. Warm effluent in tailings ponds creates open water attractive to waterfowl and shorebirds while natural water bodies remain frozen. At least 16,000 birds were observed visually flying over one tailings pond during spring migration [9] and single-day counts at (natural) McClelland and Kearl Lakes have reached 1,154 and 2,700 ducks [44]. Relative to a non-deterrent control, the odds of landing at a tailings pond protected by industry-standard bird deterrents are unacceptably high $(38 \%$ for ducks and $69 \%$ for shorebirds [9]).

Schick and Ambrock [45] considered development of the Athabasca tar sands to constitute a serious threat to migratory birds and to the Peace-Athabasca Delta. They noted that much waterfowl use during migration occurs at night which would make observation and monitoring difficult; surmised that tailings ponds could cause changes in migration habits; and noted that heavy losses of waterfowl have been observed at Wyoming, USA oil sumps and over petroleum reservoirs in the (former) USSR. Cree hunters in
Ft. Chipewyan suspect that tailings ponds may be causing changes in waterfowl migration patterns [46].

Nesting tree swallows (Tachycineta bicolor) suffered reproductive failure, high mortality, reduced body weight, elevated hepatic 7-ethoxyresorufin-O-deethylase (EROD) and thyroid hormone levels, and higher nestling parasitism rates in process-affected wetlands relative to reference wetlands [8], a result attributed to $\mathrm{PAH}$ exposure. Tree swallow hatching success, nestling weight, and fledging rate were lower at a tailings-affected wetland at Suncor than at reference sites [36]. After emerging from affected wetlands, adult insects retained PAHs, possibly through feeding or slow depuration, and thus provided a source of PAHs to insectivores such as tree swallows.

To date, birds representing 43 species and 51 taxa have died due to tailings pond exposures in the area. Although waterfowl and shorebirds have been the most-affected, dead birds of prey, gulls, passerines, and other groups have been observed also [44, 47-49]. Dyke et al. [48] noted 54 species of birds at a 0.4 ha tailings pond; Gulley [49] noted 198 species in the Suncor lease area. In April 2008, an anonymous tip alerted authorities to the death of migratory waterfowl at the Syncrude Aurora North tailings pond [50]. At that time, Syncrude admitted to the death of about 500 ducks. By July 2008, Syncrude and government were aware that 1,606 ducks had died but it was not until March 2009 that the public was informed; no information has been released to date on mortalities of other birds. Due to selfmonitoring by industry, the annual bird mortality due to tailings pond exposure is not known with certainty; it has been estimated to range from 458 to 5,037 birds (Timoney and Ronconi, unpubl. data). The problem should be considered serious until credible monitoring proves otherwise.

\section{Air Quality}

Releases of five criteria air contaminants $\left(\mathrm{PM}_{2.5}, \mathrm{PM}_{10}\right.$, total particulates, sulphur dioxide, and volatile organic compounds (VOCs), such as benzene, xylene, ammonia, and formaldehyde) and hydrogen sulphide in 2006 indicate that tar sands facilities are major polluters (Table 6). Nationally, the Syncrude Mildred Lake plant ranked in the top six of polluters for all six air contaminants in 2006. For VOCs, Canada's top four national polluters were tar sands facilities north of Ft. McMurray, the primary source of which is evaporation from tailings ponds.

Rapid increases in air emissions are predicted for the Alberta tar sands industry. By 2010, $\mathrm{PM}_{2.5}$ emissions are predicted to reach 11,200 tonnes / year (87\% above 2005 levels), while emissions of oxides of sulphur increase $38 \%$ (from 118,000 to 163,000 tonnes/year), VOCs increase $119 \%$ (from 130,000 to 285,000 tonnes / year), and nitrous oxides increase $78 \%$ (from 90,000 to 160,000 tonnes / year) [52]. North of Ft. McMurray, ambient hydrogen sulphide increased $15-68 \%$ from 1999 to 2006 depending on the location [53]. For sulphur dioxide, the trends are equally troubling: 2-62\% increase for areas north of Ft. McMurray, including a $24 \%$ increase at Ft. Mackay since 1999 and a $10 \%$ increase at Ft. Chipewyan since 2000, $200 \mathrm{~km}$ north of the tar sands facilities. While peak SO2 concentrations have reportedly decreased for most of Alberta since 1990, north of 
Table 6. Air Releases of Particulates, Sulphur Dioxide, Volatile Organic Compounds, and Hydrogen Sulphide in 2006 from Syncrude and Suncor (with Alberta and National Rank for Amount Released)*

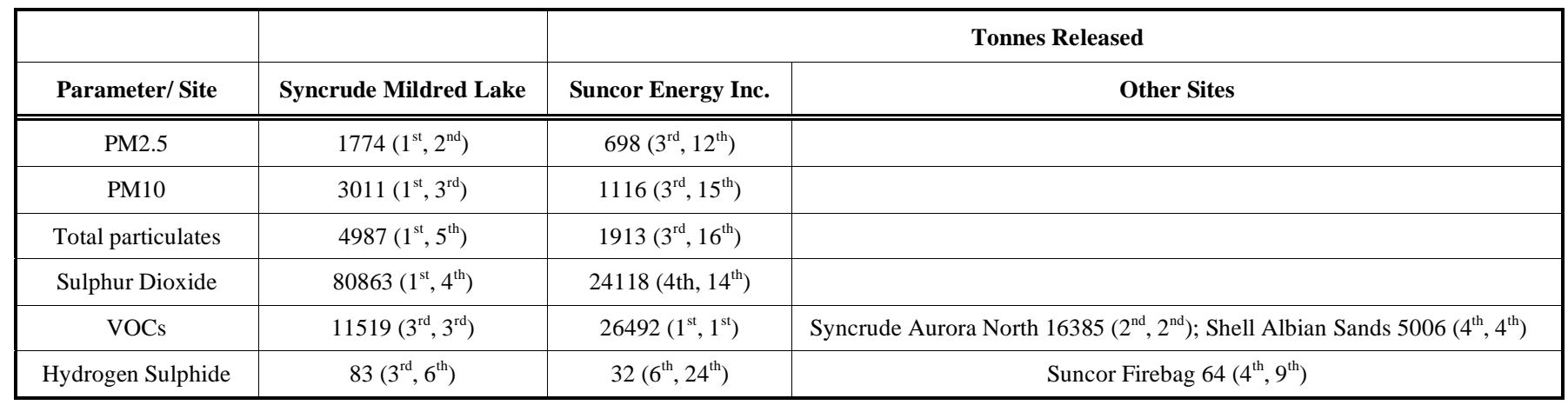

$*$ Data from NPRI [51]; facility numbers: Syncrude Mildred Lake site $=2274$, Suncor Energy Inc. Oil Sands = 2230, Syncrude Aurora North Mine $=6572$, Shell Albian Sands Energy Muskeg River Mine $=6647$; Suncor Firebag $=19181$.

Ft. McMurray they have increased 8-122\% since 1999 [53]. Similarly, peak $\mathrm{PM}_{2.5}$ concentrations have decreased for most of Alberta since 1990, but north of Ft. McMurray they have increased $17-79 \%$ since 1999.

Aluminum, potassium, sulphur, titanium, and vanadium concentrations in three lichen species were determined at 69 sites in the Athabasca tar sands by Addison and Puckett [54]. Atmospheric deposition patterns indicated by lichen thallus metal concentrations matched deposition patterns measured by physical and chemical methods. Lichen morphological damage, growth impairment, and levels of pollutants in lichen tissue are consistently highest near the major tar sands facilities [54-56]. With decreased distance to a point equidistant from the main Syncrude and Suncor plants, concentrations of sulphur, nitrogen, aluminum, chromium, iron, nickel, and vanadium show large increases in lichen tissues [57].

Some air pollutants enter the Athabasca River watershed through local deposition while others are dispersed over greater distances, e.g., east into Saskatchewan or north to the Peace-Athabasca Delta. Funneling of air pollutants by the Athabasca River valley has been documented by scientists $[54,57]$ and observed by people in Ft. Chipewyan (Fig. 5f). In Ft. Chipewyan, high gaseous mercury concentrations are often associated with a south-north airmass trajectory through the Ft. McMurray area [58]. In March 2006, southerly winds carried a mass of polluted air at least 200 $\mathrm{km}$ north from the tar sands facilities. Air trajectory analyses by Environment Canada [59-61] tracked the air to a source in the industrial tar sands area north of Ft. McMurray. Air quality monitoring in Ft. Chipewyan detected the event during which $\mathrm{PM}_{2.5}$ concentration spiked from a background of $3-5 \mu \mathrm{g} / \mathrm{m}^{3}$ to $25 \mu \mathrm{g} / \mathrm{m}^{3}$. Near Suncor, $\mathrm{N}$ to NNE and $\mathrm{S}$ to SSE winds predominate and coincide with the orientation of the Athabasca River valley [62].

During the nearly six-month period from November to late April, aerial deposition of particulate dust results in accumulations on the region's ice- and snow-covered landscape. With snowmelt in late April, accumulated pollutants are mobilized en masse in meltwater and carried into soil, ground water, and surface water. The impact of the spring pulse of pollutants requires study. Environmental and human health impacts from tar sands related air pollution will, at minimum, be regional rather than local.
Globally, the impact of tar sands development may be most evident for greenhouse gas production. Exclusive of the greenhouse gases liberated from conversion of peatlands and uplands to a mined landscape, and those liberated from later burning the synthetic fuel, annual production of carbon dioxide due to Alberta tar sands production in 2007 was estimated at 40 million tonnes [63]. Bacterial production of methane from tailings ponds increases greenhouse gas production and may impact tailings reclamation options [11]. At the Mildred Lake Settling Basin (MLSB), 60-80\% of the gas flux across the pond's surface is due to methane; the pond produces the equivalent methane of 0.5 million cattle/day [11].

\section{Water Quality: Arsenic}

Levels of arsenic in water and sediment near Ft. Chipewyan may be rising and are high in comparison to regional values. Over the period 1976-2003, lower Athabasca River dissolved arsenic mean concentration (above the detection limit) was $1.5 \mu \mathrm{g} / \mathrm{L}$; the $95^{\text {th }}$ percentile was $5.0 \mu \mathrm{g} / \mathrm{L}(\mathrm{n}=488)$ [64]). Arsenic levels in water near Ft. Chipewyan and in the lower Athabasca River exceeded those for western Lake Athabasca. In 2007, dissolved arsenic levels near Ft. Chipewyan $(2.6 \mu \mathrm{g} / \mathrm{L}$ at the town water intake); in the Rochers River near Mission Creek $(3.4 \mu \mathrm{g} / \mathrm{L})$; and in the Fletcher Channel $(1.6 \mu \mathrm{g} / \mathrm{L})$ exceeded their historical medians ( 0.6 $\mu \mathrm{g} / \mathrm{L}, 1976-87$ [28]).

Sediment arsenic concentrations in Lake Athabasca increased over the period 1970-1990, from $2 \mathrm{mg} / \mathrm{kg}$ to 10 $\mathrm{mg} / \mathrm{kg}$ [65]. Levels of arsenic in 2000 in Athabasca River sediments at Big Point Channel, Flour Bay, in the Rochers River near Mission Creek, and at the Ft. Chipewyan water intake were about $44 \%, 35 \%, 112 \%$, and $114 \%$, respectively, above the historical median levels (1976-99) reported in RAMP [28]. In 2007, sediment arsenic concentration in Lake Athabasca at the Ft. Chipewyan water intake was $9.2 \mathrm{mg} / \mathrm{kg}$ while that at the nearby Rochers River site was $9.1 \mathrm{mg} / \mathrm{kg}$ [64]. The interim freshwater guideline for protection of aquatic life is $5.9 \mathrm{mg} / \mathrm{kg}$ [66].

\section{Water Quality: Drainage from the Alsands Ditch}

Mine drainage waters carried by the Alsands Ditch into the Muskeg River resulted in water quality declines. The Alsands Ditch was constructed in 1980 in order to dewater overburden and to draw down groundwater prior to tar sands 

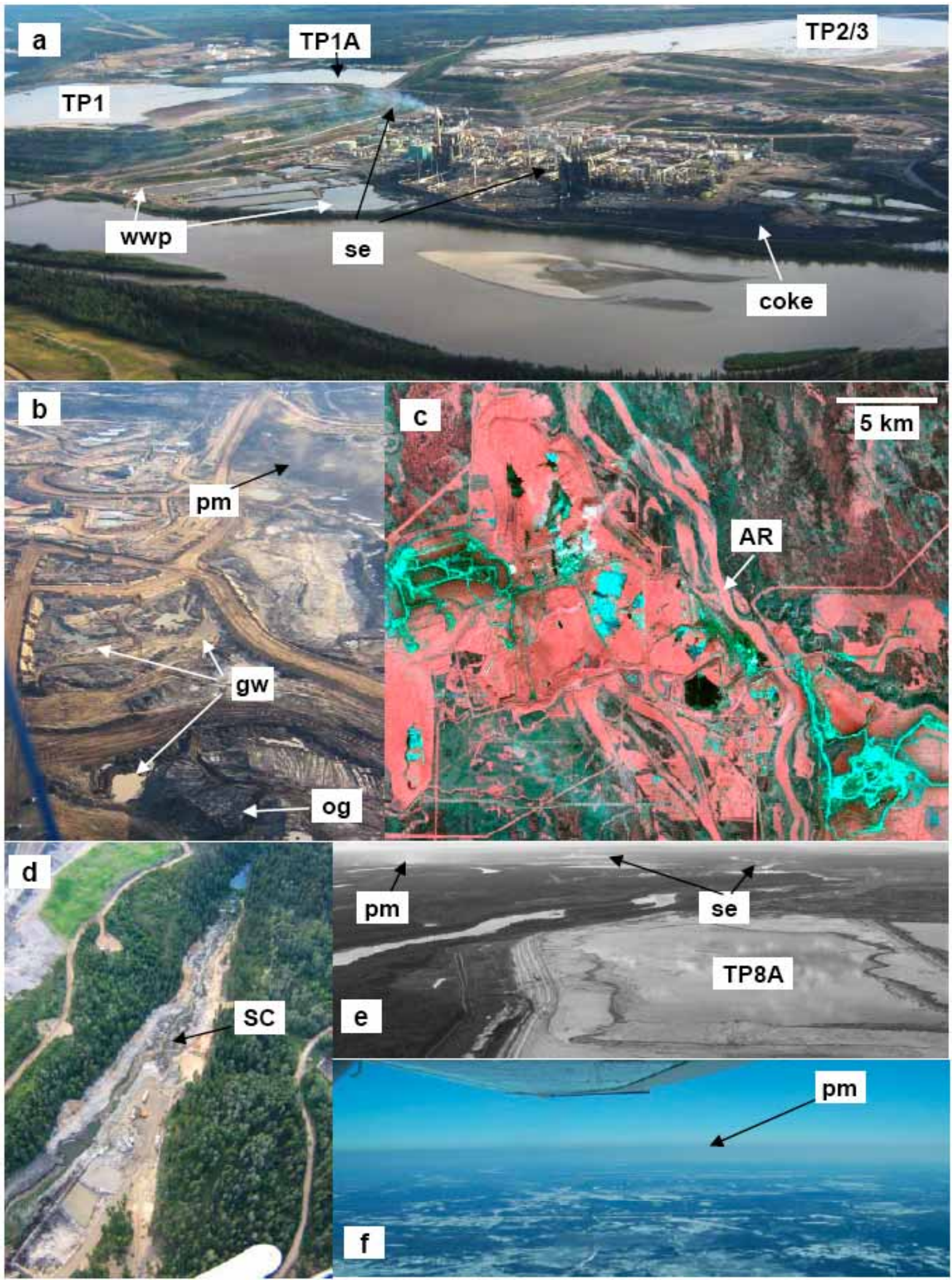

Fig. (5). Evidence of pollution and landscape degradation. (a) Stack emissions (se), wastewater ponds (wwp), numbered tailings ponds (TP), and coke-blackened landscape (coke) at Suncor main facility; Athabasca River in foreground, 10 August 2006; (b) Active strip mining and outgassing (og), degradation of groundwater ( $\mathrm{gw}$ ), and dry particulate dust (pm), area of Syncrude Aurora Mine, 10 August 2006; (c) Satellite image of facilities, stack emissions, active mines, tailings ponds, wastewater ponds, and infrastructure, straddling the Athabasca River (AR), 19 March 2008; (d) Destruction of a reach of Stanley Creek (SC), a tributary of the Muskeg River, to left is edge of Syncrude's Aurora East Pit, 10 August 2006; (e) Suncor Millennium tailings Pond 8A (TP8A) adjacent to the Athabasca River; dry particulate dust (pm) and stack emissions (se) on the horizon, 10 August 2006; (f) South to north funneling of air high in particulates (pm) is evident here north of the PeaceAthabasca Delta, 20 March 2006 (Image: M. Vassal, courtesy of S. Macmillan, Parks Canada). 
mining [26]. The ditch lies north of the lower Muskeg River at $~ 57^{\circ} 15^{\prime} 11^{\prime}$ 'N $111^{\circ} 29^{\prime} 54^{\prime}$ ' $\mathrm{W}$ [14], about eight $\mathrm{km}$ east of the Athabasca River (Fig. 1). The ditch later drained parts of the Shell Albian Mine and the Syncrude Aurora North Mine; drainage to the Muskeg River reportedly ceased in late 2002 [26].

Drainage from the Muskeg River Oil Sands Project into the Muskeg River via the Alsands Ditch began in 1998 [26]. Over the period 1997 to 2001, mean $\mathrm{pH}$ in the lower Muskeg River declined from 7.8 to 7.3 "for reasons that are not clear" [14]. Relative to the Muskeg River, the Alsands Ditch contained elevated levels of sulphate, total cations, turbidity, total dissolved solids, barium, copper, iron, strontium, uranium, and zinc and lower dissolved organic carbon [14, 26]. Total phenolics, iron, aluminum, chromium, mercury, zinc, and manganese periodically exceeded guidelines in the Alsands Ditch [26]. PAHs were exported from the Alsands Ditch to the Muskeg River; a "petroleum-like odour" was noted in the Alsands Ditch [14].

Higher sulphate levels in the lower Muskeg River in 1998 and 1999 were attributed to drainage from the Alsands Ditch, which carried affected waters from Albian Mine Pond 2 , drainage from other lease areas, and plant site runoff [33, 67]. Detection of PAHs in the Alsands Ditch and at downstream sites but not at upstream sites suggested to Alberta Environment [14] that industry may have been the source of dissolved PAHs. After completion of mine drainage operations, by fall 2006, pH of the Muskeg River had rebounded to 8.4; exceedences of sulphide, iron, and total phenols were observed [5].

Alberta government technical staff have admitted to concerns "where substantial changes in dissolved ion concentrations were associated with intermittent and largevolume releases from the Alsands Drain" [67]. Peaks in Muskeg River conductivity follow discharge events from the Albian Mine site; discharge from Albian moves down the Muskeg River as a slug of water; biotic effects may occur as a result of rapid fluctuations in ion and metal concentrations (P. McEachern, pers. comm., Alberta Environment, June 2008). The degree to which drainage of mine-affected waters into the Muskeg River affects the river's biota is not known.

\section{Water Quality: Licensed and unlicensed discharges to the Athabasca River}

Contaminant discharges to the Athabasca River are common. Here we document a few examples. At Suncor's main facility in early September 2007, industrial wastewater was diverted to Emergency Pond D to prevent materials high in oil and grease from reaching the Pond A-B-C system [68]. As water levels rose in Pond D, pumping to Pond A began. Due to human error, on 8 September the water level of Pond $\mathrm{D}$ fell below the intake of the transfer pumps, at which time bitumen and other contaminants were pumped into Pond A. Materials then flowed through Ponds $\mathrm{B}$ and $\mathrm{C}$ and into the Athabasca River; a sheen was observed on the Athabasca River below the Pond C outfall. The impact and extent of the 2007 Suncor wastewater discharge spill may never be known. The wastewater spill was about 9.8 million $\mathrm{L}$ (Alberta Environment incident number 283162). The volume and the chemical composition of the discharge incident have not been reported.
While the discharge incident was serious, routine licensed discharge from the Suncor wastewater pond system dwarfs the incident's rate. In 2007, total discharge from Suncor's wastewater pond system was 11.9 billion L [69], equivalent to $0.06 \%$ of the mean discharge of the Athabasca River at Ft. McMurray, and an annual loading of about 36.2 tonnes of metals. The total discharge of all companies is unknown.

On 6 June 1970, a Suncor pipeline break spilled three million L of oil which flowed down the Athabasca River to Lake Athabasca and was observed there for about six days $[45,70]$. The actions on the part of industry and government to contain, mitigate, and monitor the spill were perfunctory. Jakimchuk [71] found no evidence that an effort had been made to stop the downstream flow of oil, during which time the slick had travelled some $240 \mathrm{~km}$ to Lake Athabasca and Ft. Chipewyan. The impact of the spill was never studied [71].

In 1982 there was a large spill from Suncor [72]. An earlier fire that had damaged a flare area resulted in release of contaminants from a flare pond into the wastewater system. A major fire then took place on 21 January 1982 in the wastewater pond; one witness described the flames as reaching about $90 \mathrm{~m}$ in height. On 16 February, an Alberta Fish and Wildlife Officer "saw a cloudy area and then we saw a sheen on the open water, an oil sheen on the open water." "There is no evidence that in the initial period these increasing rates of emissions into the Athabasca River gave any concern to the employees of Suncor." The spill closed the commercial fishing season on Lake Athabasca and reportedly caused illnesses among people in Ft. Mackay [73, 74]. No data on contaminants in the spill were found, nor was a study conducted of the ecological and human health impacts.

\section{Water Quality: Science and Traditional Ecological Knowledge and Fish Health}

Fort Chipewyan residents have lived through many pollution events [64]. Ray Ladouceur: "That [oil spill, early 1970 s or late 1960s] buggered up our fishing... even the fish later on tasted like oil... God knows how much fish we lost..." He observed some oiled ducks. Johnny Courtereille remembered the big oil spill in spring 1968. He was out spring hunting and shot a northern pintail duck (Anas acuta) that was sitting on the water; it was coated with oil. Jumbo Fraser remembered two spills. Once, straw bales were put along the shore of Lake Athabasca to soak up oil. John Piche saw a leak from the Syncrude lease that made an oil slick in the Athabasca River. He recalled the big oil spill in the early 1980s and the shutting down of the fish plant in Ft. Chipewyan due to pollution. Ray Ladouceur remembered winter fishermen angling through the ice on Lake Athabasca during the 1980s. When they cut holes in the ice they observed oil in the water. About 15 years ago [in the 1990s], Jumbo Fraser was boating up the Athabasca River to Ft. McMurray. "There was a gush of real black looking stuff coming out of a pipe...up in a berm, quite a ways up above the river, ... gushing out... I ... got a hold of the Coast Guard... We went right back down again [with the Coast Guard] and they had shut it off [the flow from the pipe]." In about 2001 or 2002, below Suncor, Ladouceur noted that for $15 \mathrm{~km}$ there was foam in the river. "All of a sudden, I can 
see this foam coming out right about the middle of the river. There's a pump house there... Suncor. These guys seen me getting close, they went inside [the pump house]... They shut it down... They were discharging foam... Again... [in 2007] there was all kinds of foam right after [spring] break-up."

Observations of traditional elders about ecological and other changes from Ft. Chipewyan are consistent [64]. They say the river water tastes differently now: oily, sour, or salty. When river water is boiled, a brown residue remains in the pot. Fish and muskrat flesh has become soft and watery. Ducks, muskrats, and fishes taste differently now; sometimes they taste 'oily'. Inadequate information is provided to the community by outside agencies about the state of the ecosystem and human health.

Changes in taste, texture, and deformities observed in the local fishes may signal ecological degradation. Some of the changes may be chemically-induced, but others may be a food-web effect. Soft, watery flesh noted in the traditional knowledge interviews might indicate starvation. Fish consume protein when starving and replace cell mass with water. Fishes with big heads and small bodies indicate starvation which suggests reduced productivity of food organisms, a break in the food web, or direct toxicity effects. When combined, the scientific data and traditional knowledge suggest that rates of fish abnormalities may be higher than expected, may be increasing, and may be related to changes in water quality. Four metals commonly exceed fish protection threshold effects levels in Athabasca River walleye and lake whitefish: aluminum, selenium, silver, and vanadium [21]. Of these metals, selenium may present the largest risk to fish health. Selenium can contribute to reproductive failure, deformities, and death among aquatic organisms and water birds, and can adversely affect people [75].

Fish abnormalities are not necessarily related to water pollution or toxic discharges. Injury, disease, parasites, stresses related to spawning, unusual water quality conditions (e.g., high temperatures), poor nutrition, and toxic algal blooms can also cause abnormalities [76, 77]. Fish hatching alterations, increases in mortality, spinal malformations, reduced size, cardiac dysfunction, edema, and reduction in the size of the jaw and other craniofacial structures have been observed in fishes exposed to Athabasca River PAHs [78-80]. Athabasca River natural bitumen and oil-refining wastewater pond sediments caused significant hatching alterations and increases in mortality, malformations, and reduced size in young fathead minnows [81]. Edemas, hemorrhages, and spinal malformations were observed in larvae. Juvenile white suckers (Catostomus commersoni) exposed to tar sands industrial wastewater pond sediments for 96 hours demonstrated significantly increased EROD activity (30-50 fold) as compared to controls [79]. Fish embryos exposed to complex mixtures of petrogenic PAHs display a characteristic suite of abnormalities that include cardiac dysfunction, edema, spinal curvature, and reduction in the size of the jaw and other craniofacial structures [82]. Suncor's wastewater ponds are acutely toxic to fishes and are potent inducers of hepatic EROD activity [83]. Exposure of fathead minnow (Pimephales promelas) eggs and larvae to Suncor's wastewater sediment/bitumen caused a significant increase in deformities such as heart edema and spinal curvature.
Detrimental effects on fishes from tar sand industrial activity were reported by Tetreault et al. [84], who compared hepatic EROD activity in slimy sculpin from three sites on the Steepbank River. The reference site was located upstream of both natural and industrial sources of tar sands contaminants. The 'natural' site was located in an area of tar sands deposits unaffected by mining. The 'developed' site was located in an area of tar sands mining. Relative to the reference site, EROD activity at the natural site was elevated two-fold; at the developed site, it was elevated ten-fold. Levels of cytochrome CYP 1A in fish livers collected from the Athabasca River or its tributaries show large increases near tar sands mining sites [78-80], as do fish liver cells exposed to lipophilic contaminants concentrated from the Athabasca River [85]. These increases, indicative of contaminant stress, are not evident at sites affected by natural erosion of tar sands bitumen [78].

Traditional users have noted increased rates of fish deformities such as lesions, internal and external tumors, and deformed skulls, skeletons, and fins (Fig. 6). "Pushed in faces, bulging eyes, humped back, crooked tails... never used to see that. Great big lumps on them... you poke that, it sprays water..." [64]. RAMP [21] reported an overall abnormality frequency of $100 \%$ in female Athabasca River lake whitefish and walleye and of $74 \%$ in males of those species; at least $25 \%$ of female and $50 \%$ of male walleyes suffered from liver abnormalities. Paucity of relevant reference data make the abnormality frequencies difficult to evaluate.

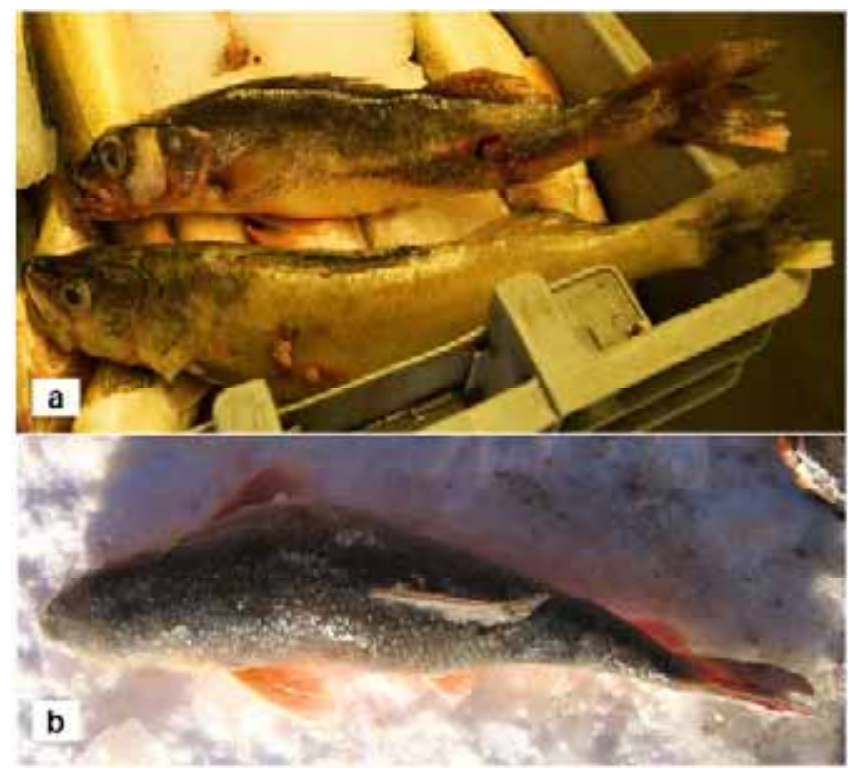

Fig. (6). Fish deformities. (a) Walleye exhibiting external tumors, lesions, scoliosis, bulging eyes, and abnormal fins, Lake Athabasca near Ft. Chipewyan, July 2007 (Image: L. Carota, Vancouver, BC). (b) Female white sucker exhibiting scoliosis (and a lesion, not visible), Quatre Fourches River near Ft. Chipewyan, 20 January 2009.

\section{Human Health Concerns}

The health risks of air particulates stem from both chronic and acute exposure. Chronic exposure is associated with cardiovascular disease, increases in respiratory symptoms, and lung cancer. Risk of an out-of-hospital 
cardiac arrest has been related to exposure to particulates at an ambient $\mathrm{PM}_{2.5}$ concentration of $\sim 15 \mu \mathrm{g} / \mathrm{m} 3$ in the hour preceding the cardiac arrest [86]. The highest $\mathrm{PM}_{2.5}$ concentrations in Alberta in 2006 were observed at the Suncor Millennium tar sands mine $\left(66 \mu \mathrm{g} / \mathrm{m}^{3}, 99^{\text {th }}\right.$ percentile $)$ [51]. Particulates are derived from stack emissions, combustion, and windblown coke dust, dry tailings, and tar sands (Fig. 5). Both the quantity and the chemical constituents of the particulates pose health concerns, as they contain not only organic contaminants such as PAHs but also a suite of metals such as vanadium, arsenic, and mercury. Occupational exposure to tar sands employees may be significant.

Elevated levels of mercury and arsenic in the local fishes are a concern. Health Canada [87] recommended that consumption of large predatory fish should not exceed one meal per week for adults. Pregnant women, women of childbearing age, and children should consume no more than one fish meal per month. Due to the nutritional value of fish, and the traditional-cultural and economic importance of fish to Ft. Chipewyan residents, fish mercury levels pose a serious dilemma.

Arsenic is a known carcinogen linked with human bile duct, liver, urinary tract, and skin cancers, vascular diseases, and Type II diabetes [88, 89]. The aquatic biota and the people who depend upon aquatic life for food are exposed to both arsenic and PAHs. Co-exposure to arsenic and the PAH benzo(a)pyrene can increase rates of genotoxicity 8-18 times above rates observed after exposure to either carcinogen in isolation $[90,91]$.

For years, the people of Ft. Chipewyan have believed that they are suffering increased rates of cancer, diabetes, and heart problems. In 2006, "22 people died here, half of cancer [in a population of about 1,163 ]. There's something wrong... There has to be something wrong.... It's killing the fish too... [About five years ago] right here at Goose Island [in the Athabasca River Delta], one spring, after breakup, there were... maybe 10,000 fish floating on [Goose Island] creek... don't know what the cause was... they were rotten, must have happened in the winter... there was whitefish, northern pike in there." "Our main killer here is our water... It's too much chemicals in our water, too much garbage in our water... The air and the water are very important, without that, we're not going to exist..." [64].

Incidences of type II diabetes, lupus, renal failure, and hypertension are elevated in Fort Chipewyan [92]. Based on a 12-year dataset (1995-2006), Chen [93] concluded that the number of cancer cases overall was $30 \%$ higher than expected $(\mathrm{p}=0.035)$, as were bile duct cancers $(\mathrm{p}=0.030)$, cancers of the blood and lymphatic system (overall $\mathrm{p}=$ 0.022 , and of leukemia, $\mathrm{p}=0.034$ ), and soft tissue sarcomas $(p=0.041)$. Exposure to environmental contaminants such as arsenic, PAHs, and mercury, particularly in "country foods", is a plausible factor for the apparent elevated rates of human cancers and other diseases in Fort Chipewyan.

\section{CONCLUSIONS}

The question "to what degree are tar sands industrial activities detectable in the ecosystems of northeastern Alberta?" was addressed in four ways.
1. Do present levels of contaminants, regardless of origin, present an ecosystem or human health concern? Yes. Data indicate that contaminants of concern include PAHs, mercury, and arsenic in the lower Athabasca River system and criteria air pollutants.

2. Is there evidence of increased levels of contaminants when sites downstream of industry are compared to sites upstream of industry? Yes. Increased levels of PAHs in the Muskeg River and of porewater metals in the Athabasca River are examples.

3. Is there evidence of increased levels of contaminants over time? Yes. Data indicate increased levels of PAHs in sediment, of mercury in fishes, of arsenic in water and sediment, and of criteria air contaminants such as $\mathrm{PM}_{2.5}$, VOCs, and sulphur dioxide. Increased rates of fish abnormalities have been observed by local fishermen.

4. Are there documented incidents of industrial pollution or degradation? Yes. Examples include spills in 196768, 1970, 1982, and 2007 into the Athabasca River. Pollution from the Alsands Ditch led to elevated levels of sulphate, cations, and various metals in the Muskeg River. Large numbers of birds die each year due to exposure to tailings ponds. Native biota have been obliterated from 65,040 ha of boreal landscape.

Given the 40-year history of licensed and unlicensed discharges into air, soil, and water, the 'baseline' predevelopment condition of the Athabasca River may have been lost long ago. Presently, we cannot quantitatively apportion contaminant levels into natural and industrial sources. The attention of the world's scientific community is urgently needed. The extent to which tar sands pollutants are affecting ecosystem and public health deserves immediate and systematic study. Short of this, the projected tripling of tar sands activities over the next decade may result in unacceptably large and unforeseen impacts.

\section{ACKNOWLEDGEMENTS}

We thank R. Cheng for landscape analyses, L. Carota for a photograph, and anonymous reviewers. J. Short, P. Hodson, D. Schindler, and P. McEachern provided helpful criticism to sections of an earlier draft.

\section{REFERENCES}

[1] NRBS (Northern River Basins Study). Northern River Basins Study: The legacy. The collective findings. Edmonton: Alberta Environmental Protection 1997.

[2] MRBB (Mackenzie River Basin Board). State of the Aquatic Ecosystem Report 2003. Ft. Smith, NT: Mackenzie River Basin Board Secretariat 2004.

[3] NREI (Northern Rivers Ecosystem Initiative). Collective Findings. Saskatoon: Environment Canada 2004.

[4] Syncrude. 2006 Groundwater Monitoring Report, Syncrude Canada Limited Aurora. Ft. McMurray: Syncrude Canada Ltd. 2007.

[5] RAMP (Regional Aquatics Monitoring Program). Regional Aquatics Monitoring Program, 2006 Technical Report, Final. Ft. McMurray: RAMP 2007.

[6] Pembina Institute. Fact or Fiction? Oil sands reclamation. Calgary: Pembina Institute 2008.

[7] Hunter G. Investigation of groundwater flow within an oil sand tailings impoundment and environmental implications. MSc Thesis, University of Waterloo 2001. 
[8] Gentes M-L. Health assessment of tree swallows (Tachycineta bicolor) nesting on Athabasca oil sands, Alberta. MSc Thesis, University of Saskatchewan 2006.

[9] Ronconi RA, St. Clair CC. Efficacy of a radar-activated on-demand system for deterring waterfowl from oil sands tailings ponds. J Appl Ecol 2006; 43: 111-9.

[10] Conly FM, Crosley RW, Headley JV. Characterizing sediment sources and natural hydrocarbon inputs in the lower Athabasca River, Canada. J Environ Eng Sci 2002; 1: 187-99.

[11] Holowenko FM, MacKinnon MD, Fedorak PM. Methanogens and sulphate-reducing bacteria in oil sands fine tailings waste. Can J Microbiol 2000; 46: 927-37.

[12] Ayles GB, Dubé M, Rosenberg D. Oil Sands Regional Aquatic Monitoring Program (RAMP), Scientific Peer Review of the Five Year Report (1997-2001). Ft. McMurray: Regional Aquatics Monitoring Program 2004.

[13] Natural Regions Committee. Natural Regions and Subregions of Alberta. Edmonton: Alberta Natural Heritage Information Centre 2006.

[14] Alberta Environment. Overview of water quality in the Muskeg River basin July 1972 to March 2001. Edmonton: Alberta Environment 2001.

[15] Morgenstern N. Geotechnics and Mine Waste Management Update. In: Seminar on Safe Tailings Dam Constructions, September 20-21, 2001. Gällivare (Sweden): Swedish Mining Association and the European Commission 2001; pp. 54-67.

[16] Komex. Ecological risk assessment problem formulation and screening assessment, Ponds 1/1A operations node. Ft. McMurray: Suncor Energy Inc. 2005.

[17] Vitt DH, Halsey LA, Thormann MN, Martin T. Peatland inventory of Alberta, Phase 1: Overview of peatland resources in the natural regions and subregions of the province. Edmonton: Alberta Environmental Protection 1996.

[18] Moss EH. Flora of Alberta. 2nd ed. Toronto: University of Toronto Press 1983.

[19] AOU (American Ornithologists' Union). Check-List of North American Birds. 7th ed. Washington: AOU 1998.

[20] Scott WB, Crossman EJ. Freshwater Fishes of Canada. Bulletin 184. Ottawa: Fisheries Research Board of Canada 1973.

[21] RAMP (Regional Aquatics Monitoring Program). Regional Aquatics Monitoring Program, 2005 Technical Report, Final. Ft. McMurray: RAMP 2006.

[22] CCME (Canadian Council of the Ministers of the Environment). Canadian Water Quality Guidelines for the Protection of Aquatic Life. Summary table, update 7.1. Ottawa: CCME 2008.

[23] Alberta Environment. Surface water quality guidelines for use in Alberta. Edmonton: Alberta Environment 1999.

[24] Erskine AJ. Birds in Boreal Canada. Report Series No. 41. Ottawa: Canadian Wildlife Service 1977.

[25] Bayne EM, Habib L, Boutin S. Impacts of chronic anthropogenic noise from energy-sector activity on abundance of songbirds in the boreal forest. Consrev Biol 2008; 22: 1186-93.

[26] Axys. Albian Sands Energy Inc. Muskeg River Mine Expansion Project. Aquatic Environmental Setting Report, Appendices. Edmonton: Alberta Environment 2005.

[27] Evans MS, Billeck B, Lockhart L, Bechtold JP, Yunker MB, Stern G. PAH sediment studies in Lake Athabasca and the Athabasca River ecosystem related to the Fort McMurray oil sands operations: sources and trends. In: Brebbia CA, Ed. Oil and Hydrocarbon Spills III, Modelling, Analysis and Control. Boston: WIT Press 2002; pp. 365-74.

[28] RAMP (Regional Aquatics Monitoring Program). Oil Sands Regional Aquatics Monitoring Program 2000, Volume I: Chemical and Biological Monitoring. Ft McMurray: RAMP 2001.

[29] Johnson L. An analysis in support of sediment quality thresholds for polycyclic aromatic hydrocarbons (PAHs) to protect estuarine fish. pah7_2000.pdf. Seattle: US National Oceanic and Atmospheric Administration, National Marine Fisheries Service 2000.

[30] Myers MS, Johnson LL, Collier TK. Establishing the causal relationship between polycyclic aromatic hydrocarbon (PAH) exposure and hepatic neoplasms and neoplasia-related liver lesions in English Sole (Pleuronectes vetulus). Hum Ecol Risk Assess 2003; 9: 67-94.

[31] Ullrich SM, Tanton TW, Abdrashitova SA. Mercury in the aquatic environment: a review of factors affecting methylation. Critic Rev Environ Sci Tech 2001; 31: 241-93.

[32] Garcia E, Carignan R. Mercury concentrations in fish from forest harvesting and fire-impacted Canadian boreal lakes compared using stable isotopes of nitrogen. Environ Toxicol Chem 2005; 24: 685-93.

[33] Golder Associates. Oil Sands Regional Aquatics Monitoring Program (RAMP) five year report. May 2003. Calgary: RAMP Steering Committee 2003.

[34] Barker J, Rudolph D, Tompkins T, Oiffer A, Gervais F, Ferguson G. Attenuation of contaminants in groundwater impacted by surface mining of oil sands, Alberta, Canada[monograph on the internet]. In: $14^{\text {th }}$ International Petroleum Environmental Conference, November 6-9, 2007: Houston, TX.[Accessed 2008 September 5] Available from: http://ipec.utulsa.edu/Conf2007/ Papers/Barker_89.pdf.

[35] Alberta Environment. Letter re: Syncrude Canada Ltd. Aurora North Mine Groundwater Monitoring Report, 24 May 2007, from B. Pretula. Edmonton: Alberta Environment 2007.

[36] Wayland M, Smits J. The ecological viability of constructed wetlands at Suncor: Population and health-related considerations in birds. Task 5. Assessment of natural and anthropogenic impacts of oil sands contaminants within the Northern River Basins. In: Conly FM, Compiler. Northern Rivers Ecosystem Initiative: Collective Findings. Saskatoon: Environment Canada 2004; pp. 48-57.

[37] Syncrude. 2005 Groundwater Monitoring Report. Submitted to Alberta Environment. Ft. McMurray: Syncrude Canada Ltd. 2006.

[38] Golder Associates. Final Report, Beaver Creek 2005 Monitoring Program. Ft. McMurray: Syncrude Canada Ltd. 2006.

[39] Alberta Environment. Letter re: Syncrude Canada Ltd. 2007 Annual groundwater monitoring report (Mildred Lake site), 9 June 2008, from K.K. Singh. Edmonton: Alberta Environment 2008.

[40] Environmental Defence. The Tar Sands' Leaking Legacy. Toronto: Environmental Defence 2008.

[41] Moorhouse J. Appendix 1 - Methodology and Sample Calculations [for Environmental Defence report The Tar Sands' Leaking Legacy]. Toronto: Environmental Defence 2008.

[42] Smith K. Petro-Canada Mackay River 2005 Annual Conservation and Reclamation Report. File X0003418000048408, land reclamation. Edmonton: Alberta Sustainable Resources Development 2006.

[43] Butterworth E, Leach A, Gendron M, Pollard B, Stewart GR. Peace-Athabasca Delta Waterbird Inventory Program: 1998-2001. Edmonton: Ducks Unlimited Canada 2002.

[44] Ronconi RA. Predicting bird oiling events at oil sands tailings ponds and assessing the importance of alternate waterbodies for waterfowl: a preliminary assessment. Can Field-Nat 2006; 120: 19.

[45] Schick CD, Ambrock KR. Waterfowl investigations in the Athabasca Tar Sands Area. Ottawa: Canadian Wildlife Service 1974.

[46] Henton D. Hunters say pollution forcing migratory birds to change flyway, impacting Cree food source[serial on the internet]. Edmonton Journal, 5 June 2008. [Accessed 2008 June 5] Available from: http://www.canada.com/edmontonjournal/news/story.html?id $=2 \mathrm{~d} 50 \mathrm{a} 3 \mathrm{c} 1-1 \mathrm{~d} 59-4764-82 \mathrm{be}-1 \mathrm{~d} 111 \mathrm{f} 6 \mathrm{ecd} 39 \& \mathrm{p}=1$

[47] Sharp PL, Birdsall DA, Richardson WJ. Inventory studies of birds on and near crown lease number 17, Athabasca Tar Sands, 1974. Environmental Research Monograph 1975-4. Ft. McMurray: Syncrude Canada Ltd. 1975.

[48] Dyke GR, Birdsall DA, Sharp PL. Test of a bird deterrent device at a tailings pond, Athabasca Oil Sands, 1974. Professional Paper 1976-1. Ft. McMurray: Syncrude Canada Ltd. 1976.

[49] Gulley JR. Factors influencing the efficacy of human effigies in deterring waterfowl from polluted ponds. MSc Thesis, University of Alberta 1980.

[50] Christian C. Tailings leak not proven: Alta. gov't[serial on the internet]. Fort McMurray Today, 30 May 2008 [Accessed 2008 
June 1] Available from: http://cgi.bowesonline.com/pedro.php? $\mathrm{id}=2 \& \mathrm{x}=$ story $\& \mathrm{xid}=404496$

[51] National Pollutant Release Inventory (NPRI)[homepage on the internet]. Annual air releases of criteria air contaminants. [Accessed 2009 March 4] Available from: http://www.ec.gc.ca/pdb/npri/ npri_home_e.cfm

[52] Alberta Environment. Alberta air emissions trends and projections. Edmonton: Alberta Environment 2007.

[53] Alberta Environment. Ambient air quality trends in Alberta. Edmonton: Alberta Environment 2007.

[54] Addison PA, Puckett, KJ. Deposition of atmospheric pollutants as measured by lichen element content in the Athabasca oil sands area. Can J Bot 1980; 58: 2323-34.

[55] Wylie E. Diversity and vitality of 10 epiphytic lichens measured over standardized sections of jack pine, white spruce and black spruce within an 11 kilometer radius from the Great Canadian Oil Sands Limited Complex in July 1977. Ft. McMurray: Great Canadian Oil Sands Ltd 1978.

[56] Pauls RW, Abboud SA, Turchenek LW. Pollutant deposition impacts on lichens, mosses, wood and soil in the Athabasca Oil Sands area. Ft. McMurray: Syncrude Canada Ltd 1996.

[57] Berryman SB, Geiser L., Brenner G. Depositional gradients of atmospheric pollutants in the Athabasca oil sands region, Canada: an analysis of lichen tissue and lichen communities. Lichen Indicator Pilot Program 2002-2003. Final report. Ft. McMurray: Wood Buffalo Environmental Association 2004.

[58] Wiens BJ, Kellerhals M, Pankratz AD. Atmospheric contribution to mercury loading in the northern aquatic systems. In: Conly FM, Compiler. Northern Rivers Ecosystem Initiative: Collective Findings. Saskatoon: Environment Canada 2004 (research paper 9); pp. 1-18.

[59] Environment Canada. Back trajectory hindcasts, WBNP, Arrival 2006032018, WBNP_24h_100_km_ 2006032018Z.png. Ottawa: Environment Canada 2006.

[60] Environment Canada. Trajectory hindcasts, Fort McMurray, Depart 2006031818, Fort_McMurray_100_km_ 2006031818Z.png. Ottawa: Environment Canada 2006.

[61] Environment Canada. (2006c) Trajectory hindcasts, Fort McMurray, Depart 2006031918, Fort_McMurray_ 100_km_2006031918Z.png. Ottawa: Environment Canada 2006.

[62] Golder Associates. Trace metals in traditional foods within the Athabasca oil sands area. Ft. McMurray: Wood Buffalo Environmental Association 2003.

[63] Environmental Defence. Canada's Toxic Tar Sands: The Most Destructive Project on Earth. Toronto: Environmental Defence 2008.

[64] Timoney KP. A study of water and sediment quality as related to public health issues, Fort Chipewyan, Alberta[monograph on the internet]. Nunee Health Board Society, Fort Chipewyan, Alberta [Accessed 2008 May 1] Available from: http://www.connectingthedrops.ca/resources

[65] Bourbonniere RA, Telford SL, Kemper JB. Depositional history of sediments in Lake Athabasca: geochronology, bulk parameters, contaminants and biogeochemical markers. Project Report No. 72. Edmonton: Northern River Basins Study 1996.

[66] CCME (Canadian Council of the Ministers of the Environment). Canadian Environmental Quality Guidelines, summary table, update 2002. Ottawa: CCME 2002.

[67] Shell. Albian Sands Energy Inc. Muskeg River Mine Expansion Project. Responses to Alberta Environment Request for Clarification of Supplemental Information Provided. Application No. 004-20809. Calgary: Shell Canada 2006.

[68] Suncor. Fort Chipewyan Community Meeting, May 6, 2008. Ft. McMurray: Suncor Energy Inc. 2008.

[69] Suncor. 2007 Annual Industrial Wastewater Report. Ft. McMurray: Suncor Energy Inc. 2008.

[70] Hogge HL, Allman RJ, Paetz MJ, Bailey RE, Kupchanko EE. Alberta Government committee report on Great Canadian Oil Sands oil spill to Athabasca River, June 6, 1970. Edmonton: Alberta Environment 1970.
[71] Jakimchuk RD. A biological investigation of the Athabasca River oil spill. Report to the Conservation Fraternity of Alberta. Edmonton: Alberta Environment 1970.

[72] Alberta Environmental Law Centre. Provincial court records from Judge Michael Horrocks' decision, R. v. Suncor Inc., 1983. Edmonton: Alberta Environmental Law Centre 2008.

[73] Struzik E. Suncor lawyer challenges his client's records. Clipping from The Edmonton Journal of 19 October 1982. Edmonton: Alberta Environmental Law Centre 1982.

[74] Struzik E. Possible impact of Suncor spills cited. Clipping from The Edmonton Journal of 23 October 1982. Edmonton: Alberta Environmental Law Centre 1982.

[75] CRBSCF (Colorado River Basin Salinity Control Forum). Supplemental Report on the 1999 review, Water Quality Standards for Salinity, Colorado River System. Bountiful (Utah): CRBSCF 1999.

[76] Yamamoto T, Macdonald RD, Gillespie DC, Kelly RK. Viruses associated with lymphocystis disease and dermal sarcoma of walleye (Stizostedion vitreum vitreum). J Fish Res Board Can 1976; 33: 2408-19.

[77] Mill TA, Sparrow-Clark P, Brown RS. Fish distribution, movement and gross external pathology information for the Peace, Athabasca, and Slave River Basins. Project Report 147. Edmonton: Northern River Basins Study 1997.

[78] Tetreault GR, McMaster ME, Dixon DG, Parrott JL. Physiological and biochemical responses of Ontario slimy sculpin (Cottus cognatus) to sediment from the Athabasca oil sands area. Water Qual Res J Canada 2003; 38:361-77.

[79] Colavecchia MV, Hodson PV, Parrott JL. CYP1A induction and blue sac disease in early life stages of white suckers (Catostomus commersoni) exposed to oil sands. J Toxicol Environ Health A 2006; 69: 967-94.

[80] Colavecchia MV, Hodson PV, Parrott JL. The relationships among CYP1A induction, toxicity and eye pathology in early life stages of fish exposed to oil sands. J Toxicol Environ Health A 2007; 70: 1542-55.

[81] Colavecchia MV, Backus SM, Hodson PV, Parrott JL. Toxicity of oil sands to early life stages of fathead minnows (Pimephales promelas). Environ Toxicol Chem 2004; 23: 1709-18.

[82] Incardona JP, Collier TK, Scholz NL. Defects in cardiac function precede morphological abnormalities in fish embryos exposed to polycyclic aromatic hydrocarbons. Toxicol Appl Pharm 2004; 196: 191-205.

[83] Parrott J, Sherry J, McMaster M. Fish health effects from oil sands wastewater discharges and naturally- occurring oil sands compounds in the Athabasca River system. Task 5. Assessment of natural and anthropogenic impacts of oil sands contaminants within the Northern River Basins. In: Conly FM, Compiler. Northern Rivers Ecosystem Initiative: Collective Findings. Saskatoon: Environment Canada 2004; pp. 38-47.

[84] Tetreault GR, McMaster ME, Dixon DG, Parrott JL. Using reproductive endpoints in small forage fish species to evaluate the effects of Athabasca oil sands activities. Environ Toxicol Chem 2003; 11: 2775-82.

[85] Parrott JL, Hodson PV, Tillitt DE, Bennie DT, Comba ME. Accumulation of fish mixed function oxygenase inducers by semipermeable membrane devices in river water and effluents, Athabasca River, August and September, 1994. Project Report No. 83. Edmonton: Northern River Basins Study 1996.

[86] Rosenthal FS, Carney JP, Olinger ML. Out-of-hospital cardiac arrest and airborne fine particulate matter: a case-crossover analysis of emergency medical services data in Indianapolis, Indiana. Environ Health Perspect 2008; 116: 631-36.

[87] Health Canada. Mercury and Human Health. It's Your Health Ottawa: Health Canada 2004.

[88] Guo HR. The lack of a specific association between arsenic in drinking water and hepatocellular carcinoma. J Hepatol 2003; 39: 383-88.

[89] Merck. Primary liver cancers (other) [homepage on the internet] [Accessed 2008 November 20] Available from: http://www.merck.com/mmhe/sec10/ch139/ch139e.html 
[90] Maier A, Schumann BL, Chang X, Talaska G, Puga A. Arsenic coexposure potentiates benzo(a)pyrene genotoxicity. Mutat Res 2002; 517: 101-11.

[91] Fischer JM, Robbins SB, Al-Zoughool M, Kannamkumarath SS, Stringer SL, Larson JS, Caruso JA, Talaska G, Stambrook PJ, Stringer JL. Co-mutagenic activity of arsenic and benzo[a]pyrene in mouse skin. Mutat Res/Gen Toxicol Environ Mutagen 2005; 588: $35-46$.

[92] Alberta Health and Wellness. 2006. Fort Chipewyan Health Data Analysis. Edmonton: Alberta Health and Wellness 2006.
[93] Chen Y. Cancer incidence in Fort Chipewyan, Alberta 1995-2006. Edmonton: Alberta Cancer Board 2009.

[94] Lutz A, Hendzel M. Survey of baseline levels of contaminants in aquatic biota of the AOSERP study area. Edmonton: Alberta Oil Sands Environmental Research Program 1976.

[95] Donald DB, Craig HL, Syrgiannis J. Contaminants in environmental samples: mercury in the Peace, Athabasca and Slave Rivers. Project Report No. 105. Edmonton: Northern River Basins Study 1996.

(C) Timoney et al.; Licensee Bentham Open.

This is an open access article licensed under the terms of the Creative Commons Attribution Non-Commercial License (http://creativecommons.org/licenses/by-nc/3.0/) which permits unrestricted, non-commercial use, distribution and reproduction in any medium, provided the work is properly cited. 